\title{
Evaluation of biochemical profile and rumen fluid parameters of sheep supplemented with Saccharomyces cerevisiae and subjected to an abrupt diet change
}

\section{Avaliação do perfil bioquímico e parâmetros do líquido ruminal de ovinos suplementados com Saccharomyces cerevisiae submetidos à troca abrupta de dieta}

\author{
Ana Paula Schmidt ${ }^{1}$; Joana Piagetti Noschang ${ }^{1}$; Nathaly Ana Carpinelli²; Claudia \\ Faccio Demarco ${ }^{3}$; Laura Valadão Vieira ${ }^{1 *}$; Antônio Amaral Barbosa ${ }^{4}$; Marcio Nunes \\ Corrêa ${ }^{5}$; Eduardo Schmitt ${ }^{6}$; Josiane de Oliveira Feijó ${ }^{3}$; Cássio Cassal Brauner ${ }^{7}$
}

\section{Highlights:}

Saccharomyces cerevisiae increased the rumen protozoal population.

Yeast reduced the deleterious effects of an abrupt diet change.

Supplemented sheep tend to have their immune status improved.

\begin{abstract}
This study examines rumen-fluid parameters and the biochemical profile of feedlot sheep supplemented with a commercial product composed of yeast culture and enzymatically hydrolyzed yeast during an abrupt change of diet. Eight sheep at 30 months of age, with an average weight of $40.2 \pm 3.4 \mathrm{~kg}$, were housed in individual stalls where they received the same diet twice daily, which was formulated according to the National Research Council [NRC] (2007). The animals were divided into two groups, namely, supplemented with Saccharomyces cerevisiae $(\mathrm{SG}, \mathrm{n}=4)$ and control $(\mathrm{CG}, \mathrm{n}=4)$. The experiment consisted of three periods: the first (seven days) consisted of an acclimation to the roughage-only diet; in the second period (five days), the animals of SG started to receive supplementation; lastly, in the third period (five days), all animals underwent a sudden change of diet, which was characterized by an alteration from 100\% roughage to a 50:50 ratio (roughage:concentrate) without prior adaptation. Blood samples were collected to evaluate albumin, aspartate amino transferase, calcium, gamma glutamyl transferase, globulins, glucose, magnesium, potassium, sodium, total plasma proteins and urea. Rumen fluid was harvested to evaluate physical aspects. Supplementation increased the protozoa count; the rate of sedimentation and fluctuation remained within the physiological parameters; and total plasma
\end{abstract}

1 Discentes do Curso de Mestrado do Programa de Pós Graduação em Zootecnia, Universidade Federal de Pelotas, UFPEL, Pelotas, RS, Brasil.E-mail: ana_psch@yahoo.com.br; joana.piagetti@hotmail.com; lauravieira96@gmail.com

2 Discente em Ciência Animal, South Dakota State University, USD, Brookins, SD, Estados da América do Sul. E-mail: nathaly. carpinelli@sdstate.edu

3 Discentes do Curso de Doutorado do Programa de Pós-Graduação em Zootecnia, UFPEL, Pelotas, RS, Brasil. E-mail: claudemarco@hotmail.com; josianeofeijo@gmail.com

4 Discente do Curso de Pós-Doutorado do Programa de Pós-Graduação em Medicina Veterinária, UFPEL, Pelotas, RS, Brasil. E-mail: antoniobarbosa.vet@hotmail.com

5 Prof. Dr., Curso de Graduação e Pós-Graduação em Medicina Veterinária, UFPEL, Pelotas, RS, Brasil. E-mail: marcio. nunescorrea@gmail,com

6 Prof. Dr., Curso de Graduação em Medicina Veterinária, UFPEL, Pelotas, RS, Brasil. E-mail: schmitt.edu@gmail.com

7 Prof. Dr., Curso de Graduação e Pós-Graduação em Zootecnia, UFPEL, Pelotas, RS, Brasil. E-mail: cassiocb@gmail.com

* Author for correspondence

Received: Mar. 23, 2020 - Approved: Aug, 20, 2020 
proteins and globulin decreased. Therefore, the yeast appears to be a promising alternative for reducing the deleterious effects of an abrupt change of diet.

Key words: Immunity. Performance. Rumen environment. Ruminants. Sheep farming. Yeast.

\section{Resumo}

Este estudo avaliou os parâmetros do líquido ruminal e o perfil bioquímico de ovinos confinados suplementados com um produto comercial composto por cultura de levedura e levedura hidrolisada enzimaticamente durante mudança abrupta de dieta. Foram utilizadas oito ovelhas, com 30 meses de idade e peso médio de $40,2 \pm 3,4 \mathrm{~kg}$, mantidas em baias individuais e receberam a mesma dieta duas vezes ao dia, formulada de acordo com o NRC (2007). Os animais foram distribuídos em dois grupos: suplementado com Saccharomyces cerevisiae (GS, $n=4)$ e controle (GC, $n=4)$. O experimento foi constituído de três períodos, o primeiro (sete dias) destinado a adaptação à dieta a base exclusivamente de volumoso, o segundo período (cinco dias) onde os animais do grupo GS passaram a receber suplementação e um último período (cinco dias) onde todos os animais sofreram mudança brusca de dieta, que foi caracterizada por alteração de $100 \%$ do volumoso para uma dieta na relação de 50:50 (volumoso:concentrado), sem adaptação prévia. Foram coletadas amostras de sangue, para avaliação de albumina, AST, cálcio, GGT, globulinas, glicose, magnésio, potássio, sódio, PPT (proteínas plasmáticas totais) e ureia. E líquido ruminal para avaliação de aspectos físicos. A suplementação aumentou a contagem de protozoários, a taxa de sedimentação e flutuação manteve-se dentro do fisiológico e houve redução em PPT e globulina mostrando-se uma alternativa promissora na redução dos efeitos deletérios da troca abrupta de dieta.

Palavras-chave: Ambiente ruminal. Imunidade. Levedura. Ovinocultura. Performance. Ruminantes.

\section{Introduction}

The constant expansion of sheep farming has led to the intensification of the production model so that better animal performance could be achieved. Accordingly, diets with a high energy content have been increasingly used in the nutrition of small ruminants (Yang, Li, McAllister, McKinnon, \& Beauchemin, 2012). This need, coupled with improper feeding management, may cause an imbalance in the rumen fermentation process, altering the symbiosis and activity of the microbial population. As a result, the risk of occurrence of metabolic disorders such as acidosis is increased (França \& Rigo, 2012).

Ruminal acidosis can be defined as a rumenfermentation disorder associated with rapid and excessive intake of easily digestible carbohydrates. Ingestion of these carbohydrates can lead to changes in the rumen $\mathrm{pH}$, with prolonged reductions to values below 6.0. This new environment promotes the growth of amylolytic bacteria and inhibits the growth of cellulolytic bacteria, causing direct negative effects on digestibility (Nagata et al., 2018). On the other hand, rumen $\mathrm{pH}$ values below 5.8 increase the production of short-chain fatty acids (SCFA) and the proliferation of lactate-using bacteria (Bannink, France, \& Lopez, 2008), making this value a threshold of vulnerability for the epithelium. Consequently, changes may take place in microbial composition, with death of protozoa (Aschenbach \& Gabel, 2000) and the possibility of a ruminal inflammatory response (Gozho, Plaizier, Krause, Kennedy, \& Wittenberg, 2005).

An abrupt change in nutrition is the main factor determining the degree of change in rumen fermentation and potential digestive disorders (Van Soest, 1994). Therefore, acidosis is a typical disease stemming from incorrect feeding management that occurs mainly when animals reared extensively start receiving diets rich in carbohydrates without 
previous adaptation, in a short time. Farenzena, Kozloski, Gindri and Stefanello (2016) observed that the microbiota of sheep that underwent an abrupt change from a pasture (Cynodon sp.) diet to a concentrate diet took at least 12 days to adapt to this change.

Therefore, the use of additives in animal feed is an alternative to maintain rumen $\mathrm{pH}$ as well as increase the efficiency and activity of microorganisms (França \& Rigo, 2012). According to the Food and Drug Administration [FDA] (2014), directfed microbials (DFM) are products that contain live microorganisms (bacteria, fungi or yeasts) and currently replace the nomenclature of probiotics.

The yeast Saccharomyces cerevisiae is one of the microorganisms most commonly used to improve rumen fermentation, milk production and feeding behavior, increase the proportion of SCFA and microbial population, reduce the ammonia content; and stabilize the $\mathrm{pH}$ (Yuan et al., 2015). The culture of this fungus consists of living yeast, yeast cell wall (composed of $\beta$-glucans and mannanoligosaccharides), vitamins, proteins, peptides, amino acids, nucleotides, lipids, organic acids, oligosaccharides, esters and alcohols (Nocek, Holt, \& Oppy, 2011).

The mechanism of action of live yeasts in the rumen environment is through the consumption of oxygen present in the rumen, which comes in small amounts adhered to the feed and is also found in the consumption of water, rumination and salivation. Most rumen microorganisms are highly sensitive to oxygen. Thus, with the removal of this gas, the environment becomes more favorable to them, increasing bacterial viability, improving rumen fermentation and minimizing said acidity (França \& Rigo, 2012).

Mannans and glucans are responsible for the local and systemic action of yeasts on the immune system. Mannan-oligosaccharides are able to bind to the fimbriae of bacteria and inhibit colonization of the gastrointestinal tract by pathogenic microorganisms. $\beta$-glucans, in turn, have an immunomodulatory effect, heightening the response to pathogens (Nocek et al., 2011).

In view of the above-described scenario, this study was carried out to examine rumen fluid parameters and the biochemical profile of feedlot sheep supplemented with a compound consisting of yeast culture and enzymatically hydrolyzed yeast during an abrupt diet change.

\section{Material and Methods}

The study was conducted at the sheep barn of the Center for Research, Teaching and Extension in Livestock (NUPEEC) of the Federal University of Pelotas (UFPEL) and was approved by the Ethics Committee on Animal Experimentation (approval no. 4100-2017).

Eight Texel $\times$ Corriedale crossed sheep with 30 months of age and average weight of $40.2 \pm$ $3.4 \mathrm{~kg}$ were housed in individual stalls where they were randomly assigned to one of two groups: supplemented or control. The supplemented group $(\mathrm{SG}, \mathrm{n}=4)$ received $8.2 \mathrm{~g} / \mathrm{sheep} /$ day of the commercial product, which was composed of yeast culture and enzymatically hydrolyzed yeast Celmanax $^{\circledR}$ (Arm \& Hammer, USA). This product was diluted in $60 \mathrm{~mL}$ of water, measured using a beaker, and administered orally with a $60-\mathrm{mL}$ syringe. Control group $(\mathrm{CG}, \mathrm{n}=4)$ received $60 \mathrm{~mL}$ of water with a syringe, aiming to mimic the stress from forced oral administration.

The animals received the same diet, which was calculated to provide $4 \%$ of live weight on a dry matter (DM) basis, in accordance with the Nutrient Requirements of Small Ruminants (NRC, 2007). Feed was supplied twice daily, once in the morning (08h30) and once in afternoon (16h30). Water was available ad libitum.

The experimental period was 17 days, of which the first seven were used for the animals to acclimate to the diet and the other 10 represented the actual 
experiment with yeast. The study was divided into three periods. Period 1 (days 01 to 07 ) referred to the adaptation with pearl millet (Pennisetum glaucum) pasture, which was harvested, chopped, weighed and supplied to the animals in the feeders and offered in the amount of $3.68 \mathrm{~kg} \mathrm{DM} /$ day. In period 2 (days 08 to 12), the amount of pearl millet offered to the sheep was increased to $4.42 \mathrm{~kg} \mathrm{DM} /$ day, and each group started to receive the respective treatment. At the start of period 3 (days 13 to 17), in addition to the treatment, the animals were subjected to an abrupt change of diet, to a roughage:concentrate ratio of
50:50, with the roughage consisting of maize silage and the concentrate of wheat bran $(1.66: 0.86 \mathrm{~kg}$ $\mathrm{DM} /$ day).

Samples of pearl millet were collected on the last day of period 2 (day 12 of the experimental period), whereas the maize silage and wheat bran samples were collected on the last day of period 3 (day 17). This material was used for chemical analyses of the diet (Table 1). In these evaluations, the DM content was determined by oven-drying the samples at 105 ${ }^{\circ} \mathrm{C}$ for $24 \mathrm{~h}$; and mineral matter (MM), by placing the samples in a muffle furnace at $600{ }^{\circ} \mathrm{C}$ for $4 \mathrm{~h}$.

\section{Table 1}

Chemical composition of the feedstuffs used in the composition of the diet of sheep subjected to an abrupt diet change, for control group $(n=4)$ and the group supplemented with $8.2 \mathrm{~g} / \mathrm{sheep} / \mathrm{day}$ of hydrolyzed yeast and yeast culture $(n=4)$

\begin{tabular}{ccccccc}
\hline \multirow{2}{*}{ Ingredient } & \multicolumn{7}{c}{ Percent (\%) } \\
\cline { 2 - 7 } & $\mathrm{DM}^{1}$ & $\mathrm{MM}^{2}$ & $\mathrm{CP}^{3}$ & $\mathrm{EE}^{4}$ & $\mathrm{NDF}^{5}$ & $\mathrm{ADF}^{6}$ \\
\hline Pearl millet & 66.38 & 9.07 & 13.20 & 3.00 & 56.50 & 30.00 \\
Maize silage & 40.78 & 2.64 & 11.60 & 3.34 & 46.10 & 20.30 \\
Wheat bran & 84.50 & 4.25 & 19.30 & 2.34 & 44.50 & 9.80 \\
\hline
\end{tabular}

Note. ${ }^{1}$ Dry matter; ${ }^{2}$ Mineral matter; ${ }^{3}$ Crude protein; ${ }^{4}$ Ether extract; ${ }^{5}$ Neutral detergent fiber; ${ }^{6}$ Acid detergent fiber.

Following the same methodology adopted by Demarco et al. (2019), crude protein (CP) was measured by the Kjeldahl method. The neutral and acid detergent fiber contents were analyzed as proposed by Mertens (2002), whereby the samples were weighed in filter bags and treated with neutral detergent in an Ankom Fiber Analyzer (ANKOM Technology, Macedon NY, USA). Ether extract was determined in a reflux system using ethyl ether at $180{ }^{\circ} \mathrm{C}$, for $4 \mathrm{~h}$.

Rumen fluid and blood were harvested on the last day of each period (days 7, 12 and 17), two hours after the morning feed supply. The rumen fluid was collected through an oro-ruminal probe, with the first jets being discarded to eliminate contamination by saliva and the content being stored in sterile flasks for immediate evaluation of physical (color, smell, consistency and sedimentation-flotation test
(SFT)), chemical ( $\mathrm{pH}$ and methylene blue reduction time (MBRT)) and microbiological (motility and protozoa count) parameters.

For SFT, $10 \mathrm{~mL}$ of rumen fluid were added to a falcon tube and the time during which the feed particles rested until stratified layers were formed was recorded. The $\mathrm{pH}$ was measured using a portable digital $\mathrm{pH}$ meter (HANNA ${ }^{\circledR}$ Instrumenters Brasil). Lastly, MBRT was determined by adding $0.5 \mathrm{~mL}$ of methylene blue (2\%) to $9.5 \mathrm{~mL}$ of rumen fluid sample (González, Corrêa, \& Silva, 2014)

The protozoa count was performed by the technique described by Dehority (1997), following the principle of preserving the material in a formaldehyde solution to maintain the morphological structures. The material obtained from the collections $(5 \mathrm{~mL})$ was preserved in $50-\mathrm{mL}$ 
falcon tubes to which $10 \mathrm{~mL}$ of $37 \%$ formalin were added. After the content was homogenized, tubes were kept under refrigeration.

Blood samples were collected before the morning feed supply by jugular vein puncture, using the Vacutainer system (Vacuplast ${ }^{\circledR}$, Shandong, China). Samples were collected in two tubes: one with sodium fluoride, to obtain plasma to determine glucose levels, and the other with silica (clot activator), to obtain serum for the analysis of urea, albumin, total plasma proteins (TPP), gamma glutamyl transferase (GGT), aspartate amino transferase (AST), calcium (Ca), magnesium $(\mathrm{Mg})$, sodium $(\mathrm{Na})$ and potassium $(\mathrm{K})$, using commercial kits (Labtest, MG, Brazil). The globulin content was obtained by subtracting the concentrations of TPP and albumin. Biochemical analyses were carried out using the Labmax ${ }^{\circledR}$ Plenno automatic biochemical analyzer (Labtest).
The experiment was laid out in a completely randomized design in which the obtained data were analyzed using SAS statistical software (Statistical Analysis System Institute [SAS Institute], 2016). Means were analyzed considering the groups (supplemented group and control group), the treatment period and their interactions. Analysis of variance with repeated measures was used in the Mixed Models model and means were compared by the Tukey-Kramer test, adopting statistical differences at $p \leq 0.05$.

\section{Results}

The $\mathrm{pH}$ values for the control and supplemented groups were higher $(\mathrm{p} \leq 0.05)$ in periods 1 and 2 than in period 3. However, this parameter remained within the physiological levels during the study (Figure 1).

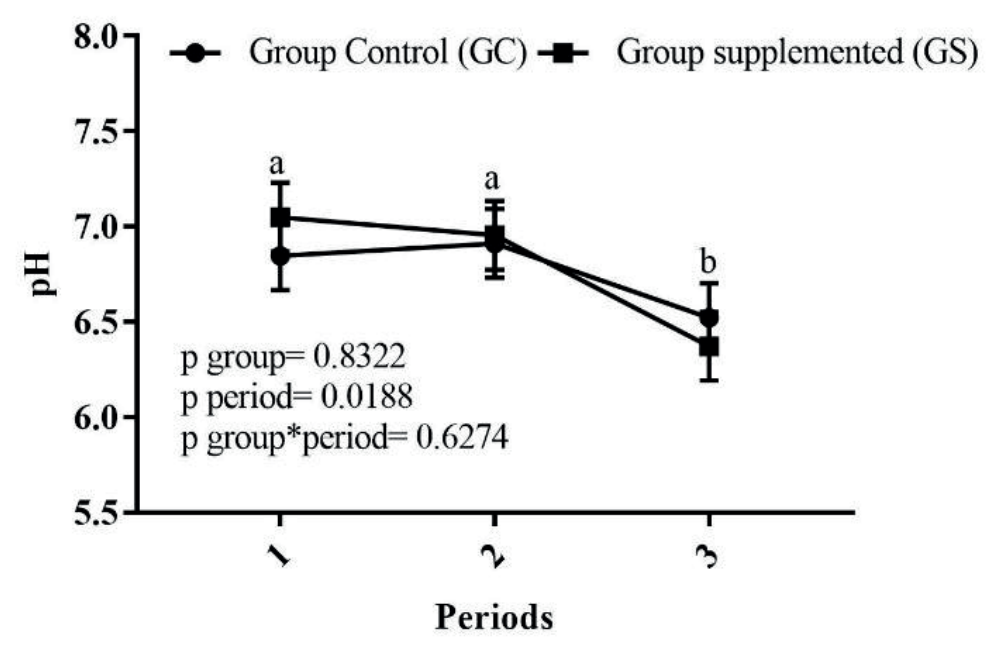

Figure 1. Mean rumen $\mathrm{pH}$ values obtained from the collection of rumen fluid in the last days of each experimental period, from the group supplemented with $8.2 \mathrm{~g} /$ sheep/day of hydrolyzed yeast and yeast culture $(S G, n=4)$ and control group $(C G, n=4)$. Period 1 : adaptation with roughage-based diet without supplementation. Period 2: roughage-based diet with supplementation. Period 3: roughage:concentrate-based diet with supplementation. ${ }^{\mathrm{A}, \mathrm{B}}$ Uppercase letters indicate differences between periods. $\mathrm{G}^{*} \mathrm{P}=$ group vs. period interaction, $\mathrm{p}=0.6274$. 
As regards the physical traits of the rumen fluid, an olive green color predominated during periods 1 and 2 and a gray color in period 3 . The smell remained aromatic in all experimental periods, a characteristic of healthy animals. Consistency remained slightly viscous in periods 1 and 2 and slightly watery in period 3. Table 2 describes the results obtained for evaluations of SFT, MBRT and protozoal motility, revealing an effect of supplementation on the SFT values. The animals supplemented with Celmanax ${ }^{\circledR}$ had shorter flotation and sedimentation periods as compared with those in $\mathrm{CG}(\mathrm{p}=0.0483)$. There was also a period effect for this variable, whose lowest values were observed in period $2(\mathrm{p}=0.0128)$. The longest MBRT was found in period $3(\mathrm{p}=0.0009)$, without no effects of supplementation.

\section{Table 2}

Rumen fluid parameters of SFT, MBRT and protozoal motility in sheep subjected to an abrupt diet change, in control group $(\mathrm{CG}, \mathrm{n}=4)$ and group supplemented with $8.2 \mathrm{~g} / \mathrm{sheep} / \mathrm{day}$ of hydrolyzed yeast and yeast culture $(\mathrm{SG}, \mathrm{n}=4)$ according to each period

\begin{tabular}{|c|c|c|c|c|c|c|c|c|c|c|}
\hline \multirow{2}{*}{$\begin{array}{l}\text { Rumen fluid } \\
\text { parameter }\end{array}$} & \multicolumn{2}{|c|}{ Period 1} & \multicolumn{2}{|c|}{ Period 2} & \multicolumn{2}{|c|}{ Period 3} & \multicolumn{3}{|c|}{ P-value } & \multirow{2}{*}{$\begin{array}{l}\text { Standard } \\
\text { deviation }\end{array}$} \\
\hline & $\mathrm{CG}^{1}$ & $\mathrm{SG}$ & $\mathrm{CG}$ & $\mathrm{SG}$ & $\mathrm{CG}$ & $\mathrm{SG}$ & Group & Period & $\mathrm{G}^{*} \mathrm{P}$ & \\
\hline $\mathrm{SFT}^{3}(\mathrm{~min})$ & $5.84^{\mathrm{A}}$ & $4.54^{\mathrm{A}}$ & $3.51^{\mathrm{B}}$ & $3^{\mathrm{B}}$ & $5.81^{\mathrm{A}}$ & $4.30^{\mathrm{A}}$ & 0.04 & 0.01 & 0.71 & 0.626 \\
\hline $\operatorname{MBRT}^{4}(\min )$ & $2^{\mathrm{A}}$ & $2^{\mathrm{A}}$ & $3^{\mathrm{A}}$ & $3^{\mathrm{A}}$ & $7.51^{\mathrm{B}}$ & $5.33^{\mathrm{B}}$ & 0.36 & 0.0009 & 0.44 & 0.99 \\
\hline Motility $^{5}$ & ++ & +++ & ++ & +++ & ++ & +++ & 0.08 & 0.75 & 0.75 & 0.33 \\
\hline
\end{tabular}

Note. ${ }^{1}$ CG: control group. ${ }^{2}$ SG: supplemented group. Period 1: adaptation with roughage-based diet without supplementation. Period 2: roughage-based diet with supplementation of $8.2 \mathrm{~g}$ Celmanax ${ }^{\circledR}$. Period 3: concentrate:roughage-based diet with supplementation of $8.2 \mathrm{~g} \mathrm{Celmanax}{ }^{\circledR} .{ }^{3}$ SFT: sedimentation and flotation test. ${ }^{4}$ MBRT: methylene blue reduction time. ${ }^{3}$ Motility: + (low), ++ (moderate),+++ (high) and ++++ (very high). G*P: group vs. period interaction. ${ }^{\mathrm{A}, \mathrm{B}}$ Different uppercase letters in the same row indicate a difference between the evaluated periods.

There was an interaction effect between the different treatment periods in relation to the evaluated groups of animals $(\mathrm{p}=0.0374)$. In this way, the rumen ciliated protozoal population increased in the in animals of $\mathrm{SG}$ in relation to those of $\mathrm{CG}(\mathrm{p}=0.0013)$. However, this increase is only significant if we compare periods 1 vs. 3 and periods 2 vs. 3 ( $\mathrm{p}=0.0374$ ) (Figure 2).

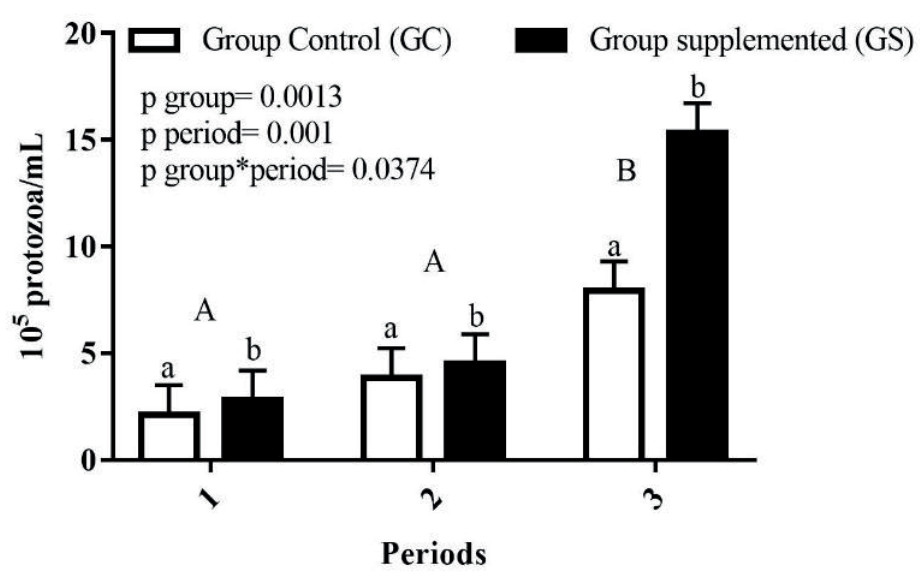

Figure 2. Mean number of protozoa $/ \mathrm{mL}$ of rumen fluid from feedlot sheep subjected to an abrupt diet change in the different experimental periods. Control group: animals receiving a basal diet. Supplemented group: animals receiving a basal diet plus supplementation with Saccharomyces cerevisiae. G*P: Group vs. period interaction. Uppercase letters indicate statistical differences between periods. Lowercase letters indicate statistical differences between groups. *Difference in the interaction between groups and periods. 
The AST values were above the physiological threshold ( 0 to $90 \mathrm{U} / \mathrm{L}$ ) in the studied periods, and the same was true for the GGT enzyme, whose physiological value is $0-32 \mathrm{U} / \mathrm{L}$. Glucose was shown to be higher than the normal parameters of $50-80 \mathrm{mg} / \mathrm{dL}$ in period 3 , in both studied groups. Globulin (35-37 g/L) and TPP (60-70 g/ $\mathrm{dL}$ ) were below the physiological value (Table 3 ).
Despite these variations, there was an interaction effect between treatment and period only for the following metabolites: globulin $(p=0.0016)$ and TPP $(p=0.0057)$. The concentrations of glucose $(\mathrm{p}=0.0014)$ and urea $(\mathrm{p}=0.0315)$ were highest in period 3. The minerals $\mathrm{Ca}(\mathrm{p}=0.0088)$ and $\mathrm{K}$ $(\mathrm{p}=0.0001)$ were found at lower values in the same period.

Table 3

Mean and standard deviation of biochemical parameters in sheep subjected to an abrupt diet change, in control group (CG, $n=4)$ and group supplemented with $8.2 \mathrm{~g} / \mathrm{sheep} /$ day of hydrolyzed yeast and yeast culture (SG, $\mathrm{n}$ =4)

\begin{tabular}{|c|c|c|c|c|c|c|c|c|c|c|}
\hline \multirow{2}{*}{ Parameter } & \multicolumn{2}{|c|}{ Period 1} & \multicolumn{2}{|c|}{ Period 2} & \multicolumn{2}{|c|}{ Period 3} & \multicolumn{3}{|c|}{ P-value } & \multirow{2}{*}{$\begin{array}{l}\text { Standard } \\
\text { deviation }\end{array}$} \\
\hline & $\mathrm{CG}$ & SG & $\mathrm{CG}$ & $\mathrm{SG}$ & $\mathrm{CG}$ & SG & Group & Period & G*P & \\
\hline $\mathrm{ALB}^{1}(\mathrm{~g} / \mathrm{dL})$ & 2.04 & 1.89 & 1.9 & 1.94 & 1.48 & 1.79 & 0.5674 & 0.0621 & 0.2932 & 0.14 \\
\hline $\mathrm{AST}^{2}(\mathrm{U} / \mathrm{L})$ & 112.5 & 110.5 & 151.75 & 205 & 110.25 & 176.75 & 0.1193 & 0.1027 & 0.4803 & 29.39 \\
\hline $\mathrm{Ca}^{3}(\mathrm{mg} / \mathrm{dL})$ & $10.44^{\mathrm{B}}$ & $10.98^{\mathrm{B}}$ & $11.87^{\mathrm{A}}$ & $11.80^{\mathrm{A}}$ & $10.85^{\text {В }}$ & $10.41^{\mathrm{B}}$ & 0.9916 & 0.0088 & 0.4491 & 0.38 \\
\hline $\mathrm{GGT}^{4}(\mathrm{U} / \mathrm{L})$ & 48.5 & 50.5 & 57.75 & 58.75 & 56.25 & 54 & 0.9492 & 0.2021 & 0.8966 & 4.74 \\
\hline $\mathrm{GLU}^{5}(\mathrm{mg} / \mathrm{dL})$ & $68.50^{\mathrm{B}}$ & $68.25^{\text {в }}$ & $64.75^{\mathrm{B}}$ & $65.00^{\mathrm{B}}$ & $81.50^{\mathrm{A}}$ & $93.25^{\mathrm{A}}$ & 0.3916 & 0.0014 & 0.466 & 5.31 \\
\hline $\mathrm{GLO}^{6}(\mathrm{~g} / \mathrm{dL})$ & $3.56^{\mathrm{B}}$ & $4.42^{\mathrm{B}}$ & $4.14^{\mathrm{B}}$ & $4.06^{\mathrm{B}}$ & $6.14^{\mathrm{A}}$ & $4.00^{\mathrm{A}}$ & 0.136 & 0.0132 & 0.0016 & 0.35 \\
\hline $\mathrm{K}^{7}(\mathrm{mmol} / \mathrm{L})$ & $5.72^{\mathrm{A}}$ & $5.41^{\mathrm{A}}$ & $5.30^{\mathrm{A}}$ & $5.19^{\mathrm{A}}$ & $4.11^{\mathrm{B}}$ & $3.82^{\mathrm{B}}$ & 0.194 & $<0.0001$ & 0.8669 & 0.2 \\
\hline $\mathrm{Mg}^{8}(\mathrm{mg} / \mathrm{dL})$ & 2.4 & 2.48 & 2.23 & 2.3 & 2.29 & 2.36 & 0.3787 & 0.2325 & 0.999 & 0.1 \\
\hline $\mathrm{TPP}^{9}(\mathrm{~g} / \mathrm{dL})$ & 56.0 & 63.2 & 60.5 & 60.1 & 76.3 & 57.9 & 0.195 & 0.0891 & 0.0057 & 0.35 \\
\hline $\mathrm{UR}^{10}(\mathrm{mg} / \mathrm{dL})$ & $32.50^{\mathrm{B}}$ & $30.75^{\text {B }}$ & $27.50^{\mathrm{B}}$ & $29.25^{\mathrm{B}}$ & $48.50^{\mathrm{A}}$ & $40.33^{\mathrm{A}}$ & 0.5643 & 0.0315 & 0.6904 & 5.51 \\
\hline
\end{tabular}

Note. ${ }^{1}$ Albumin; ${ }^{2}$ Aspartate amine transferase; ${ }^{3}$ Calcium; ${ }^{4}$ Gamma glutamyl transferase; ${ }^{5}$ Glucose; ${ }^{6} \mathrm{Globulin}$; ${ }^{7}$ Potassium; ${ }^{8}$ Magnesium; ${ }^{9}$ Total plasma proteins; ${ }^{10}$ Urea. Period 1: adaptation with roughage-based diet without supplementation. Period 2: roughage-based diet with supplementation. Period 3: concentrate:roughage-based diet with supplementation. G*P: Group vs. period interaction. ${ }^{\mathrm{A}, \mathrm{B}}$ Uppercase letters indicate differences between periods.

\section{Discussion}

The main reason for incorporating yeasts into the ruminant diet is to prevent changes in the ruminal flora, especially in animals consuming high levels of concentrate feeds (França \& Rigo, 2012). Studies show that the use of this type of additive can increase the proportion of bacteria present in the rumen-fibrolytic bacteria, mainly. These are largely responsible for reducing oxygen levels in the rumen and degrading fibrous structural carbohydrates, hemicellulose and cellulose, which contributes to digestibility (França \& Rigo, 2012). This benefit can be seen in the SFT measured in this study, which remained within the physiological parameters (4 to $8 \mathrm{~min}$ ) as described by González et al. (2014). Regarding the difference between the groups, it is suggested that the yeast stimulated bacterial activity in the rumen, improving its environment. Nutrient degradation was also enhanced, since yeasts contribute to the constant supply to the bacterial population, thereby allowing an increase in population and, consequently, in digestibility, which explains the results obtained by 
the supplemented group (Mao, Mao, Wang, Liu, \& Yoon, 2013)

There is evidence that yeast supplementation is more efficient in animals that consume larger amounts of concentrate (França \& Rigo, 2012), considering that a larger proportion of concentrate feed relative to roughage results in an imbalance in the rumen fermentation process (França \& Rigo, 2012). As a consequence, lactic acid production increases due to the rapid fermentation of nonfibrous carbohydrates and the intense production of SCFA in the rumen. This culminates in a $\mathrm{pH}$ decline (Steele, Alzahal, Walpole, \& Mcbride, 2012), since one of the effects of adding Saccharomyces cerevisiae to the diet is to control lactic acid production, which in turn affects the $\mathrm{pH}$.

The mechanism of regulation of the rumen $\mathrm{pH}$ consists of an increase in the population of rumen protozoa. This is because these microorganisms ferment starch more slowly than amylolytic bacteria, having SCFA as fermentation products, instead of lactate (Kozloski, 2016). In addition, yeast favors the anaerobic environment for the lactate-using bacteria, which prevent an excessive decrease in $\mathrm{pH}$ (Kozloski, 2016).

In the present study, the yeast did not influence the rumen $\mathrm{pH}$. This finding disagrees with the results published by Tripathi and Karim (2010), who demonstrated the efficiency of yeast in stabilizing the rumen $\mathrm{pH}$ possibly by stimulating ciliated protozoa capable of consuming lactate and digesting starch granules, thus competing for the same substrate with amylolytic bacteria. The same was observed in the study led by Reis et al. (2018), who evaluated fistulated Santa Inês sheep induced to acidosis. In the current study, the animals were supplemented with Saccharomyces cerevisiae and showed a higher $\mathrm{pH}$ when compared with the control group (n =6). However, the $\mathrm{pH}$ results differed only between the periods, with an average of 7.0 seen in periods 1 (animals fed only roughage) and 2 (animals fed roughage with yeast addition). In period 3 , there was a reduction in the average $\mathrm{pH}$ of the animals to 6.5 , which is probably due to the abrupt change of diet. Although there were variations in this parameter, the rumen $\mathrm{pH}$ fluctuated between 6.2 and 7.0 , remaining within the physiological standards.

The analysis of MBRT reflects the anaerobic fermentative metabolism of rumen bacteria. A reduction time of up to 3 min represents overactive microbiota, which may be shorter when highconcentrate diets are used, due to rapid fermentation. A MBRT between 3 and 6 min means that microbial activity is medium, whereas periods longer than 6 min may be indicative of diets that are difficult to digest or a case of ruminal acidosis (González et al., 2014).

In the third experimental period, methylene blue took a longer time to be reduced even with concentrate feed, which may be related to the abrupt change of diet, since the rumen needs a time of seven to fourteen days of adaptation of the microflora (Gonçalves, 2015). This parameter may have been influenced by the rumen $\mathrm{pH}$ decline, which also occurred in the third period, as this change compromises the activity of cellulolytic bacteria, giving space to amylolytic and protozoal bacteria (Kozloski, 2016).

The results of this study are in agreement with those reported by Borges, Silva and Fioravante (2002), who investigated parameters of the rumen fluid of feedlot sheep subjected to increasing levels of an energy-protein mineral mixture. The authors found that at the more acidic $\mathrm{pH}$ (fasting), MBRT was longer, decreasing at the peak of alkalinity. In the present study, MBRT was not influenced by the use of yeast.

The inclusion of the yeast Saccharomyces cerevisiae in the diet of feedlot sheep positively influenced the protozoal population (Figure 2), which was likely due to the improvement in the rumen environment resulting from the consumption of oxygen present in it. Oxygen consumption favors the proliferation of total strictly anaerobic bacteria, 
which serve as a source of energy and protein for protozoa, since the latter have a predatory attitude towards bacteria (Pinloche et al., 2013). In addition, the yeast cell wall consists mainly of protein and carbohydrate, which contains glucose and mannose sugars, increasing the concentration of protozoa due to the nutritional effects they promote (Mao et al., 2013).

The present results also corroborate those described by Arakaki, Stahringer, Garret and Dehority (2000), who observed an increase in the proportion of protozoa of the genera Dasytricha and Isotricha after using supplementation with Saccharomyces cerevisiae, which has the ability to consume $\mathrm{O}_{2}$, creating favorable conditions for the ecological growth and activity of anaerobic microflora (França \& Rigo, 2012). Ding et al. (2014) also observed an interaction between the roughage:concentrate ratio and yeast addition, with the treated animals showing an increase in number of total bacteria, fungi, protozoa and lactate-using bacteria and in the rate of fiber degradation. The high count of protozoa in the supplemented group is also in agreement with the results of Dolezal, Dolezal and Trinacty (2005), who supplemented 36 cows in the initial third of lactation with yeast culture (Saccharomyces cerevisiae) and observed a positive correlation between the increasing dose of yeast culture and the significant increase in the number of rumen protozoa.

As regards the organoleptic traits, the color of the rumen fluid in periods 1 and 2 of the study was olive green, which is characteristic of diets composed of roughage feedstuffs. However, in period 3, when concentrate was included, the rumen fluid was greyish, a color characteristic of acidosis. However, the mean $\mathrm{pH}$ was not acidic and the animals showed no clinical signs. The viscosity and smell of the rumen fluid was within the physiological parameters for all groups, in the different periods, corroborating the descriptions González et al. (2014), who set standards according to different diets.
In view of the above, there was no significant result for the MBRT or $\mathrm{pH}$ data. This may be linked to the high DM content of pearl millet, which hinders the digestion process, increases rumination rates and acts on the buffering of rumen $\mathrm{pH}$.

The evaluated sheep showed greater hepatic metabolism during period 3 of the study, which can be confirmed by the GGT and AST values. Although there was no statistical difference between the groups and the periods, these metabolites increased by $28.25 \%$ and $4.75 \%$, respectively, when we compare periods 2 and 3 for the supplemented group. In addition, during period 3, GGT and AST increased by $2.25 \%$ and $66 \%$, respectively, when compared with control group.

The lower TPP and globulin levels in the supplemented group may be related to the improved immune system resulting from the action of $\beta$-glucans and mannan-oligosaccharides present in the yeast wall (Czech et al., 2018). These compounds basically act to increase phagocytic cellsmacrophages, mainly_-, improving the response to antigens. Furthermore, recent studies describe that $\beta$-glucan can stimulate the expression of several immunological factors in the body (Czech et al., 2018). Within TPP, globulins are proteins that play an important role in immunity, acting as indicators of inflammatory processes (González et al., 2014).

The increase in glucose seen in the last period may be related to the switch from a high-fiber diet to a high-energy diet. Propionate is the main precursor of glucose in ruminants, as it has the ability to enter the Krebs cycle as succinyl-CoA and, through various biochemical reactions, it can originate glucose through gluconeogenesis (Kozloski, 2016) causing an increase in blood glucose levels. The change of diet also changed the urea levels: in period 3 , the concentrations of this metabolite were higher than the reference range of $8-20 \mathrm{mg} / \mathrm{dL}$ established by González et al. (2014). This may suggest that the high levels of urea in the present study may be related to the protein content of the diet, since there 
was a $17.7 \%$ increase in $\mathrm{CP}$ with the diet change. Therefore, we may infer that urea can be used as a sensitive and immediate indicator of protein intake (González et al., 2014).

\section{Conclusions}

The addition of the yeast Saccharomyces cerevisiae to the diet of sheep during an abrupt change of diet provided positive effects on rumen fluid sedimentation-flotation and increased the number of protozoa present in the rumen. Additionally, it induced a reduction in the levels of total plasma proteins and globulins in the supplemented group, showing to be a promising alternative for mitigating the deleterious effects of an abrupt change of diet. However, further research with a larger sample size is needed to confirm the results obtained in the present study.

\section{Acknowledgments}

The authors thank the Graduate Programs in Animal Science (PPGZ) and Veterinary (PPGV) of the Federal University of Pelotas; the Center for Research, Teaching and Extension in Livestock (NUPEEC); and the advisors and co-advisors, for their support.

\section{References}

Arakaki, L. C., Stahringer, R. C., Garrett, J. E., \& Dehority, B. A. (2000). The effects of feeding monensin and yeast cultures, alone or in combination, on the concentration and generic composition of rumen protozoa in steers fed on low-quality pastures supplemented with increasing levels of concentrate. Animal Feed Science and Technology, 84(1-2), 121127. doi: 10.1016/S0377-8401(00)00108-5

Aschenbach, J. R., \& Gabel, G. (2000). Effect and absorption of histamine in sheep rumen: significance of acidotic epithelial damage. Journal of Animal Science, 78(2), 464-470. doi: 10.2527/2000.782464x

Bannink, A., France, J., \& Lopez, S. (2008). Modelling the implications of feeding strategy on rumen fermentation and functioning of the rumen wall. Animal Feed Science Technology, 143(1-4), 3-26. doi: 10.1016/j.anifeedsci.2007.05.002

Borges, N. C., Silva, L. A. F., \& Fioravante, M. C. S. (2002). Avaliação do suco ruminal de bovinos "a fresco" e após 12 horas. Ciência Animal Brasileira, 3(2), 57-63. Recuperado de https://www.revistas. ufg.br/vet/article/view/280

Czech, A., Smolczyk, A., Ognik, K., Wlazło, Ł., Nowakowicz-Dębek, B., \& Kiesz, M. (2018). Effect of dietary supplementation with Yarrowia lipolytica or Saccharomyces cerevisiae yeast and probiotic additives on haematological parameters and the gut microbiota in piglets. Research in Veterinary Science, 119(6), 221-227. doi: 10.1016/j.rvsc.2018.06.007

Dehority, B. A. (1997). Classification and morphology of rumen protozoa. Columbus: University of Ohio.

Demarco, C. F., Mumbach, T., Freitas, V. O., Raimondo, R. F. S., Gonçalves, F. M., Corrêa, M. N.,... Cassal, C. B. (2019). Effect of yeast products supplementation during transition period on metabolic profile and milk production in dairy cows. Tropical Animal Health and Production, 51(8), 2193-2201. doi: 10.1007/s11250-019-01933-y

Ding, G., Chang, Y., Zhao, L., Zhou, Z., Ren, L., \& Meng, Q. (2014). Effect of Saccharomyces cerevisiae on alfalfa nutrient degradation characteristics and rumen microbial populations of steers fed diets with different concentrate-to-forage ratios. Journal of Animal Science and Biotechnology, 5(1), 24. doi: 10. 1186/2049-1891-5-24

Dolezal, P., Dolezal, J., \& Trinacty, J. (2005). The effect of Saccharomyces cerevisiae on ruminal fermentation in dairy cows. Czech Journal. Animal Science, 50(11), 503-510. doi: 10.17221/4255-CJAS

Farenzena, R., Kozloski, G. V., Gindri, M., \& Stefanello, S. (2016). Minimum length of the adaptation and collection period in digestibility trials with sheep fed ad libitum only forage or forage plus concentrate. Journal of Animal Physiology and Animal Nutrition, 101(5), 1057-1066. doi: 10.1111/jpn.12550

Food and Drug Administration (2014). CPG Sec. 689.100 direct-fed microbial products.

França, R. A., \& Rigo, E. J. (2012). Utilização de leveduras vivas (Saccharomyces cerevisiae) na nutrição de ruminantes - Uma revisão. $F A Z U \mathrm{em}$ Revista, 2(8), 187-195.

Gonçalves, W. C. (2015). Efeito do periodo de adaptação $e$ de colheita sobre os resultados em ensaios de metabolismo com ovinos. Itapetinga: UESB. 
González, F. H. D., Corrêa, M. N., \& Silva, S. C. (2014). Transtornos metabólicos nos animais domésticos. Porto Alegre: Universidade Federal do Rio Grande do Sul.

Gozho, G. N., Plaizier, J. C., Krause, D. O., Kennedy, A. D., \& Wittenberg, K. M. (2005). Subacute ruminal acidosis induces ruminal lipopolysaccharide endotoxin release and triggers an inflammatory response. Journal of Dairy Science, 88(4), 13991403. doi: 10.3168/jds.S0022-0302(05)72807-1

Kozloski, G. B. (2016). Bioquímica dos ruminantes. Santa Maria: Universidade Federal de Santa Maria.

Mao, H. L., Mao, H. L., Wang, J. K., Liu, J. X., \& Yoon, I. (2013). Effects of Saccharomyces cerevisiae fermentation product on in vitro fermentation and microbial communities of low-quality forages and mixed diets. Journal of Animal Science, 91(7), 32913298. doi: 10.2527/jas.2012-5851

Mertens, D. R. 2002. Gravimetric determination of amylase-treated neutral detergent fiber in feeds with refluxing in beaker or crucibles: collaborative study, Journal of AOAC International, 85(6), 1217-1240. doi: $10.1093 /$ jaoac/85.6.1217

Nagata, R., Kim, Y. H., Ohkubo, A., Kushibiki, S., Ichijo, T., \& Sato, S. (2018). Effects of repeated subacute ruminal acidosis challenges on the adaptation of the rumen bacterial community in Holstein bulls. Journal of Dairy Science, 101(5), 4424-4436. doi: 10.3168/jds.2017-13859

National Research Council (2007). Nutrient requirements of small ruminants: sheep, goats, cervids, and new world camelids. Washington, DC: National Academy Press.

Nocek, J. E., Holt, M. G., \& Oppy, J. (2011). Effects of supplementation with yeast culture and enzymatically hydrolyzed yeast on performance of early lactation dairy cattle. Journal of Dairy Science, 94(8), 40464056. doi: 10.3168/jds.2011-4277

Pinloche, E., McEwan, N., Marden, J. P., Bayourthe, C., Auclair, E., \& Newbold, C. J. (2013). The effects of a probiotic yeast on the bacterial diversity and population structure in the rumen of cattle. PloS One, 8(7), e67824. doi: 10.1371/journal.pone.0067824
Reis, L. F., Sousa, R. R., Oliveira, F. L. C., Rodrigues, F. A. M. L., Araújo, C. A. S. C., Meira, E. B. S., Jr., \& Ortolani, E. L. (2018). Comparative assessment of probiotics and monensin in the prophylaxis of acute ruminal lactic acidosis in sheep. BMC Veterinary Research, 14(1), 9. doi: 10.1186/s12917-017-12 64-4

Statistical Analysis System Institute (2016). Help and documentation. SAS 9.1.3. Cary, NC: SAS Institute Inc.

Steele, M. A., Alzahal, O., Walpole, M. E., \& Mcbride, M. E. (2012). Short communication: grain-induced subacute ruminal acidosis is associated with the differential expression of insulin-like growth factorbinding proteins in rumen papillae of lactating dairy cattle. Journal of Dairy Science, 95(10), 6072-6076. doi: 10.3168/jds.2011-4864

Tripathi, M. K., \& Karim, S. A. (2010). Effect of individual and mixed live yeast culture feeding on growth performance, nutrient utilization and microbial crude protein synthesis in lambs. Animal Feed Science and Technology, 155(2-4), 163-171. doi: 10.1016/j.anifeedsci.2009.11.007

Van Soest, P. J. (1994). Nutritional ecology of the ruminant. New York: Cornell University Press.

Yang, W. Z., Li, Y. L., McAllister, T. A., McKinnon, J. J., \& Beauchemin, K. A. (2012). Wheat distillers grains in feedlot cattle diets: feeding behavior, growth performance, carcass characteristics, and blood metabolites. Journal of Animal Science, 90(4), 13011310. doi: $10.2527 /$ jas.2011-4372

Yuan, K., Liang, T., Muckey, M. B., Mendonça, L. G. D., Hulbert, L. E., Elrod, C. C., \& Bradford, B. J. (2015). Yeast product supplementation modulated feeding behavior and metabolism in transition dairy cows. Journal of Dairy Science, 98(1), 532-540. doi: $10.3168 /$ jds.2014-8468 
